\title{
CONDUCTIVITY OF INTRACELLULAR ELECTROLYTES AS A QUICK INDICATOR OF THE VIABILITY OF SCOTS PINE SEEDLINGS AFTER WINTERING IN FIELD CONDITIONS
}

\author{
Jacek Banach*, Kinga Skrzyszewska, Maria Novokreshchenova, \\ Marta Kempf
}

Department of Ecology and Silviculture, Faculty of Forestry,

University of Agriculture in Krakow, al. 29 Listopada 46, 31-425 Krakow

\section{ABSTRACT}

The aim of the study was to analyse the viability and differentiation of the degree of low temperature resistance of one-year-old Scots pine (Pinus sylvestris L.) seedlings after wintering in the field. Nursery material was grown from seeds collected from 4 seed objects growing in the following forest districts: Kędzierzyn (P1), Chrzanów (P2), Rudy Raciborskie (P3) as well as seed orchard in the Miechów Forest District (P0). In addition, a sample of seedlings showing signs of damage (P4) was also analysed (Table 1). The electrical conductivity of electrolytes released from shoots (SEL - Shoot Electrolyte Leakage) and roots (REL - Root Electrolyte Leakage) of pine seedlings were measured. The obtained results were compared with the assessment of the electrical conductivity $(E C)$ of the shoot and root (the so-called admittance) of the same seedlings. Using the regression equations, the relationship between seedling growth parameters and SEL and REL values was estimated. Containerized pine seedlings, hibernating in external production beds, have shown a greater share of damage caused by low temperature compared to bare root seedlings, wintering in artificial substrate. Differentiation between individual provenances was demonstrated in terms of all analysed viability indices, which suggests a different degree of resistance of cell membranes to the damage caused by low temperature (Table 2). Classification of seedlings as damaged or non-

* $ه$ jacek.banach@urk.edu.pl 
viable based on a visual assessment of the occurrence of signs of damage was confirmed in $80 \%$ by measuring their viability (Fig. 1 ). Along with the increase in height and size of the seedling sturdiness quotient (SQ), the share of seedlings showing damage to the root system increased - showing a higher REL value (Fig. 2). Based on the research, it is recommended to test the viability of the seedlings at the end of the winter, even if no signs of damage had been observed, as the damage may have occurred at the cellular level. Assessment of the level of electrolyte leakage from root and shoot cells released as a result of frost damage is a good and quick indicator of seedling viability.

\section{KEYWORDS}

frost damage $\bullet$ vitality $\bullet$ admittance $\bullet R E L \bullet S E L$

\section{Introduction}

Most research into frost resistance and tolerance of low temperatures concerns herbaceous plants, arable crops, cereals, or the model plant Arabidopsis thaliana, while work on woody species is scarce (Sakai and Larcher 1987, Gusta et al. 2009, Wiśniewski and Gusta 2014). The cell membrane plays the major role in resistance to low temperature due to its peripheral location in the cell, which is at the border between the external environment and the cytoplasm. Ion management and water balance depend on its stability (Rakowski 2005). The reaction to cold is membrane depolarization. The calcium channels are opening, which causes an increase in the concentration of calcium ions in the cytoplasm (Floryszczak-Wieczorek 2007). Frost mainly causes damage to the cell membrane due to the formation of ice crystals, which are the immediate cause of excessive leakage of electrolytes from tissues (Rakowski 2005). Also important is the adaptability, which is affected by processes such as changes in membrane properties, hormone levels, sugar content, and gene expression. Kurbidaeva and Novokreshchenova (2011) report that an increase in abscisic acid (ABA) content in cells is associated with the plant's resistance to cold and frost.

Nursery production is one of the most important breeding activities carried out in the State Forests in Poland, with an aim to obtain high-quality planting material. Seedlings grown in nurseries using container technology are often exposed to thermal environmental stress. Among the main causes of damage to seedlings are prolonged winter frosts combined with a lack of snow cover and rapid temperature drops occurring every few years at the beginning of winter, or spring frosts that often appear (Wilczyński et al. 2005, Wesoły and Pukacki 2009). Seedlings in nursery containers are most exposed to freezing of the root system. Roots with a diameter below $2 \mathrm{~mm}$ freeze quickly. Root damage to seedlings can range from $80 \%$ to $100 \%$. Seedlings assessed visually do not necessarily present clear external signs of damage or of reduced viability. Damage can occur at the plant cell level. Hence the need to assess the viability of seedlings and their physiological condition (Wesoły and Pukacki 2009). Planting seedlings with reduced viability generates additional costs associated with the need to make adjustments and improvements in the next growing seasons. 
In order to assess the viability of seedlings, the most commonly used methods include the measurement of electrical conductivity $(E C)$ (admittance) and the method of electrolyte leakage from the roots ( $R E L$ - Root Electrolyte Leakage). Brønnum (2005) stated that the REL measurement is the best indicator of viability assessment for Abies procera, as it shows statistical significance for each examined feature. Similarly, Edwards (1998) observed a correlation between the value of this index and the survival of seedlings within the crop. Higher REL values correspond to lower survival. Stattin and Lindström (1999) confirmed this correlation also for Pinus sylvestris. In turn, a clear correlation between the survival of seedlings and their physiological condition, determined by the amount of admittance, was demonstrated by Wesoły et al. (1998). Wesoły and Pukacki (2009) reported that starting from March, the value of admittance begins to increase, and its value may indicate a progressing physiological activity in shoots when there are no signs of spring development yet (i.e. swelling of buds).

The objective of the present study was to assess the viability of one-year-old Scots pine (Pinus sylvestris) seedlings after wintering in the field. The usefulness of measuring the electrical conductivity of electrolytes released from damaged the cells of shoot (SEL - Shoot Electrolyte Leakage) and roots (REL - Root Electrolyte Leakage) of pine seedlings was investigated. Both indicators were compared with the assessment of the electrical conductivity $(E C)$ of the shoot and root of the same pine seedlings, i.e. the measurement of admittance - the method recommended when assessing seedling viability. Correlations between seedling growth parameters and the values of SEL and $R E L$ were also determined.

\section{Material and methods}

\section{Study material}

The assessment of the physiological state of seedlings was carried out at the beginning of the growing season (March 2017). One-year-old pine seedlings grown in the container nursery at Rudy Raciborskie Forest District and under plastic grow tent at the Didactic and Research Station in Krynica were analysed. The evaluated planting material came from 4 seed sources from the Kędzierzyn Forest District (P1), Chrzanów Forest District (P2), Rudy Raciborskie Forest District (P3) and seed orchard in the Miechów Forest District. The reference sample (P0) consisted of seedlings with bare root system, grown from the seeds from seed orchard, under plastic grow tent. Due to the unavailability of mycorrhizal seedlings, non-mycorrhizal ones were used. Seedlings of Kędzierzyn origin with clear signs of frost damage were obtained for the last analysed sample (P4). In each sample, except the reference one, 40 seedlings were evaluated (Table 1).

In the container nursery, one-year-old pine seedlings (samples 1-4) were grown on a peat substrate with the addition of perlite (5\%) and a mycorrhizal biopreparation containing the mushroom Hebeloma crustuliniforme, produced in the laboratory in Nędza (Rudy Raciborskie Forest District). As a reference sample, one-year-old bare 
root seedlings were obtained, grown under controlled conditions under plastic grow tent on a substrate composed of high peat (50\%) and fir and spruce sawdust (50\%). Seedlings wintered in the production field in Hiko V-120ss containers. Before measuring the electrical conductivity $(E C)$, the shoot height $(\mathrm{SH})$ and root collar diameter (RCD) of the seedling were measured, and the seedling sturdiness quotient (SQ) was calculated as the ratio $\mathrm{SH}: \mathrm{RCD}$.

Table 1. Origin of Scots pine seeds of the analysed seedling material

\begin{tabular}{|c|c|c|c|c|c|c|}
\hline \multirow{2}{*}{$\begin{array}{l}\text { Symbol } \\
\text { of the } \\
\text { sample }\end{array}$} & \multirow{2}{*}{$\begin{array}{l}\text { Region } \\
\text { of origin }\end{array}$} & \multirow{2}{*}{ Forest district } & \multicolumn{2}{|c|}{$\begin{array}{l}\text { Geographical } \\
\text { coordinates }\end{array}$} & \multirow{2}{*}{$\begin{array}{c}\text { Number } \\
\text { of seedlings }\end{array}$} & \multirow{2}{*}{$\begin{array}{c}\text { Type } \\
\text { of seedlings }\end{array}$} \\
\hline & & & $\begin{array}{l}\text { Longitude } \\
\text { (E) }\end{array}$ & $\begin{array}{l}\text { Latitude } \\
\text { (N) }\end{array}$ & & \\
\hline P0 & So60 & Miechów & $20^{\circ} 00^{\prime}$ & $50^{\circ} 30^{\prime}$ & 32 & $\begin{array}{l}\text { bare root, } \\
\text { non-mycorrhizal }\end{array}$ \\
\hline P1 & So60 & Kędzierzyn & $19^{\circ} 26^{\prime}$ & $50^{\circ} 01^{\prime}$ & 40 & \multirow{4}{*}{$\begin{array}{l}\text { containerized, } \\
\text { mycorrhizal }\end{array}$} \\
\hline $\mathrm{P} 2$ & So50 & Chrzanów & $18^{\circ} 18^{\prime}$ & $50^{\circ} 53^{\prime}$ & 40 & \\
\hline P3 & So50 & Rudy Raciborskie & $18^{\circ} 25^{\prime}$ & $50^{\circ} 13^{\prime}$ & 40 & \\
\hline $\mathrm{P} 4$ & \multicolumn{2}{|c|}{$\begin{array}{l}\text { Seedlings with clear signs of } \\
\text { damage, of Kędzierzyn origin } \\
\text { - field assessment }\end{array}$} & $19^{\circ} 26^{\prime}$ & $50^{\circ} 01^{\prime}$ & 40 & \\
\hline
\end{tabular}

Determination of electrical conductivity $(E C)$ of root and shoot (admittance)

Electrical conductivity $(E C)$ was determined in two points of the shoot - at a distance of $1.5 \mathrm{~cm}$ from the apical bud $\left(A d m_{1.5}\right)$ and in the middle of the seedling $\left(A d m_{1 / 2}\right)$. The root system was measured $1 \mathrm{~cm}$ below the root collar $\left(A d m_{s k}\right)$. Admittance was measured with an Elmetron CC-401 conductivity meter equipped with a CKI-01 sensor. The obtained values were compared with the critical values provided by Wesoły et al. (2004) and Wesoły and Pukacki (2009). If the reading value was $25 \mu \mathrm{S}$ and lower, then seedlings were classified as viable; values between 26 and $259 \mu$ S signified partial frost damage to cell membranes; while at values above $260 \mu \mathrm{S}$ seedlings were considered dead. The admittance measurement at two points on the shoot was used to assess the degree of seedlings activation. The seedlings for which the value of admittance measured on a shoot at a distance of $1.5 \mathrm{~cm}$ from the apical bud was above $30 \mu \mathrm{S}$ were classified as physiologically active (Wesoły et al. 2004, Wesoły and Pukacki 2009, Wesoły and Hajdasz 2014). 


\section{Determination of electrolyte leakage from roots and shoots}

The assessment of electrolyte leakage from fine roots was carried out according to the modified method proposed by McKay (1992) for coniferous species. From the root system of the seedlings, all roots $<2 \mathrm{~mm}$ in diameter were taken from a $2 \mathrm{~cm}$ segment, which were cut between 3 and $5 \mathrm{~cm}$ from the root collar. The obtained roots were weighed to the nearest $0.001 \mathrm{~g}$ and then placed in a $30 \mathrm{ml}$ test tube, whereupon $16 \mathrm{ml}$ of distilled water, for which the electrical conductivity $\left(E C_{0}\right)$ had been measured previously, was poured. The prepared tubes were shaken and then placed at room temperature for 24 hours. After this time, the conductivity of cell electrolytes $\left(E C_{24}\right)$ was measured (Mckay 1992). The solution from each tube was poured into another tube, and the roots were placed in a freezer at the temperature of $-20^{\circ} \mathrm{C}$ for 12 hours for complete destruction of the cell walls (Kurbidaeva et al. 2014). The root samples were then combined with the solutions that were previously poured away, and shaken for further 12 hours. After this period, the electrolyte electrical conductivity $\left(E C_{\max }\right)$ was measured with an Elmetron CC-401 conductivity meter with an EC-210 sensor. The relative leakage of root electrolytes $(R E L)$ was calculated according to the following formula:

$$
R E L=\frac{E C_{24}-E C_{0}}{E C_{\max }-E C_{0}} \cdot 100 \%
$$

Also, the value of electrolyte leakage from $1 \mathrm{~g}$ of fresh root mass was calculated, by dividing the electrical conductivity of the solution after cell wall destruction $\left(E C_{\max }\right)$ by the mass of the root sample. The relative leakage of intracellular electrolytes was also determined for shoots (SEL). $2 \mathrm{~cm}$ long shoot samples were obtained at a distance of 5 to $7 \mathrm{~cm}$ from the top of the seedling, and then the procedure continued as in the case of roots, except the shoots were frozen for 24 hours.

The obtained REL values were compared with the cut-off value, which for Scots pine grown in containers is $30 \%-R E L 30$. This is the maximum value of the indicator of relative electrolyte leakage, above which the weakened seedling viability causes significant falls within forest crops of this species (Edwards 1998). The relative electrolyte leakage above 50\% - SEL50 was adopted as the cut-off value for the SEL index (Brzóstowicz and Prokowski 2003, Kurbidaeva et al. 2014).

To assess the viability of seedlings and their suitability for planting within the crops, a method for assessing the leakage of electrolyte from $1 \mathrm{~g}$ fresh root mass $\left(E L_{1 g}\right)$ (Stattin and Lindström 1999) was also used, assuming the minimum value of $400 \mu \mathrm{S} \cdot \mathrm{cm}^{-1} \cdot \mathrm{g}^{-1}$, below which the seedlings were considered damaged.

The average value of the analysed parameter was calculated for each seedling sample and the minimum and maximum values were assigned. To determine the statistical significance of differences between means for individual samples, a one-way analysis of variance (constant model) was used (StatSoft Inc. 2017). The regression relationship between the height, the thickness at the root collar, and the coefficient of seedling viability versus the relative leakage of electrolytes from roots and shoots was also analysed. 


\section{Results}

In the sample of P0 seedlings wintering in nursery substrate, the minimum relative electrolyte leakage from shoots (SEL) was $10.7 \%$ and the maximum was $56.2 \%$, with 9.4\% of the seedlings exceeding the SEL50 tissue damage cut-off-value. Root electrolyte leakage $(R E L)$ ranged from $8.2 \%$ to $50.6 \%$. The adopted root damage cut-off value REL30 was exceeded only in the case of $3.1 \%$ of the seedlings. Assessment of seedling viability on the basis of electrolyte leakage from 1 gram of fresh root mass showed that $9.4 \%$ of seedlings may have had root system damage. Based on the admittance value measured at the root collar, no viable seedlings were observed in the analysed reference sample (P0), whereas both measurements carried out on the shoot indicated a large share of seedlings showing a high degree of spring awakening (Table 2, Fig. 1).

In the P1 sample, i.e. in the seedlings originating from the Kędzierzyn Forest District, the minimum electrolyte leakage from shoots was $5.5 \%$, and the maximum, $74.0 \%$. Only $7.5 \%$ of the seedlings exceeded the SEL50 value. The minimum electrolyte leakage from the roots was $26.9 \%$, and the maximum was $96.1 \%$. The REL30 cut-off value has exceeded for as much as $97.4 \%$ of the seedlings, which means that almost all seedlings suffered from minor root damage. The large share of non-viable seedlings has not been confirmed by the admittance measurement at the root collar (only $21.1 \%$ ). Also, neither of the admittance measurements carried out on the shoot showed a high degree of spring awakening of seedlings (Table 2, Fig. 1).

In the P2 sample from the Chrzanów Forest District, the range of variability of electrolyte leakage from shoots was determined by the values of $13.8 \%$ and $100.6 \%$, with only $7.5 \%$ of seedlings exceeding the SEL50 value. The minimum leakage of electrolytes from the roots was $16.7 \%$, and the maximum was $86.0 \%$, with $51.4 \%$ of seedlings exceeding the REL30 value. A large share of potentially non-viable seedlings was also found when measuring admittance at the root collar (70.3\%), while the measurement of admittance on shoots did not confirm a large share of seedlings showing physiological activity (Table 2, Fig. 1).

In the P3 sample obtained from container seedlings grown from the seeds originating in the Rudy Raciborskie Forest District, the minimum electrolyte leakage from shoots was $14.7 \%$, and the maximum was $37.1 \%$. This means that no seedlings have exceeded the SEL50 level, adopted as the maximum allowable. The minimum electrolyte leakage from the roots was $22.4 \%$, and the maximum leakage was $40.3 \%$, however as much as $55 \%$ of seedlings exceeded the maximum level of REL30. Measurement of admittance on the shoot, in particular in the middle of its length, indicated a very high proportion of physiologically active seedlings (Table 2, Fig. 1).

In the P4 sample, consisting of container seedlings of Kędzierzyn origin with signs of clear frost damage, the minimum leakage of electrolytes from shoots was $6.0 \%$ and the maximum was $31.3 \%$, therefore none of the seedlings exceeded the SEL50 cut-off value for shoots. The values of electrolyte leakage from the roots were in the range of 20.1-97.9\%, with $77.5 \%$ of seedlings exceeding the maximum (cut-off value) REL30. A large share of potentially non-viable seedlings was also shown by the measurement 


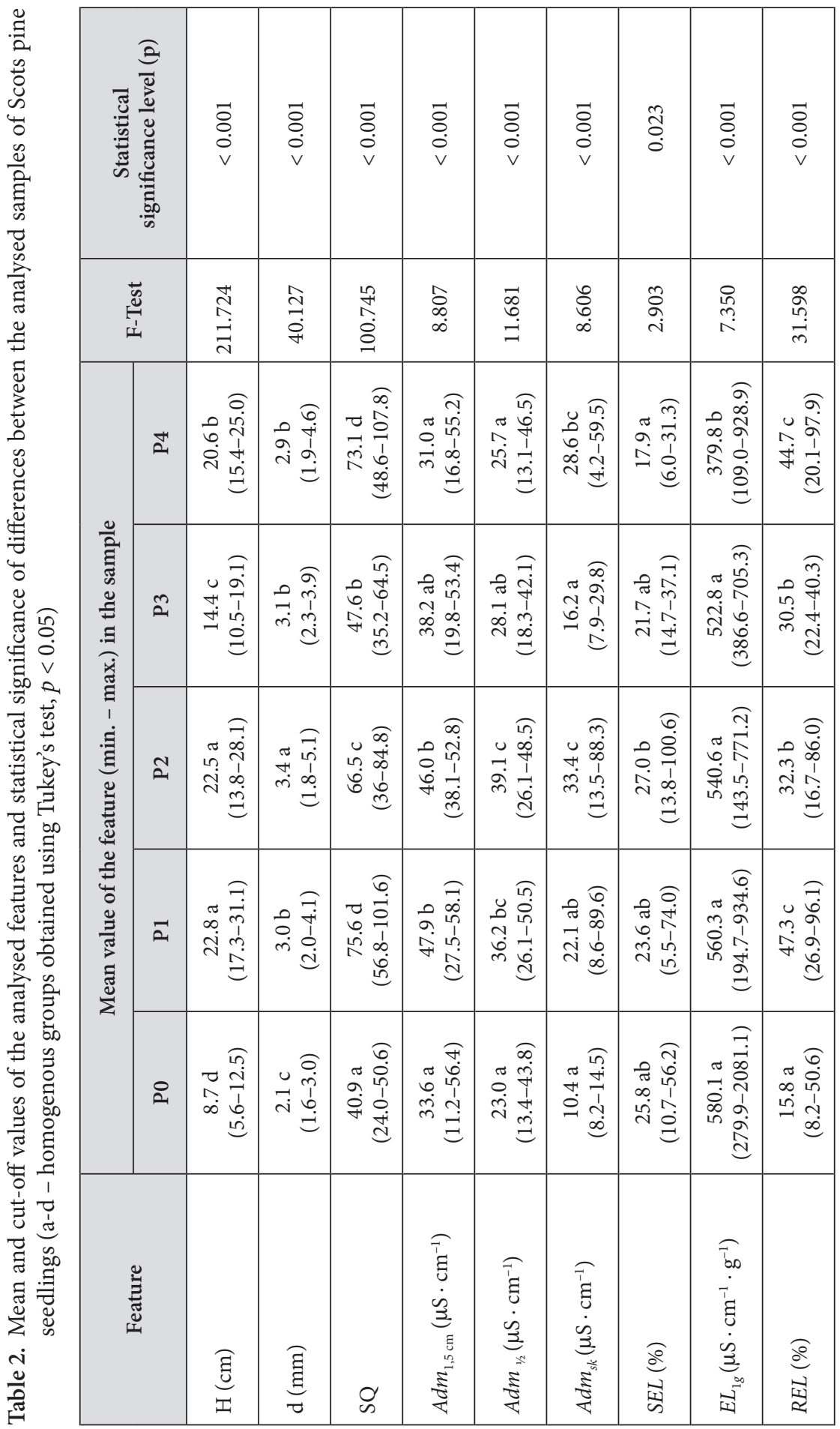


of admittance at the root collar (45.0\%), while admittance measurement in the middle and at the top of the shoot showed a large share of seedlings showing physiological activity (Table 2, Fig. 1).

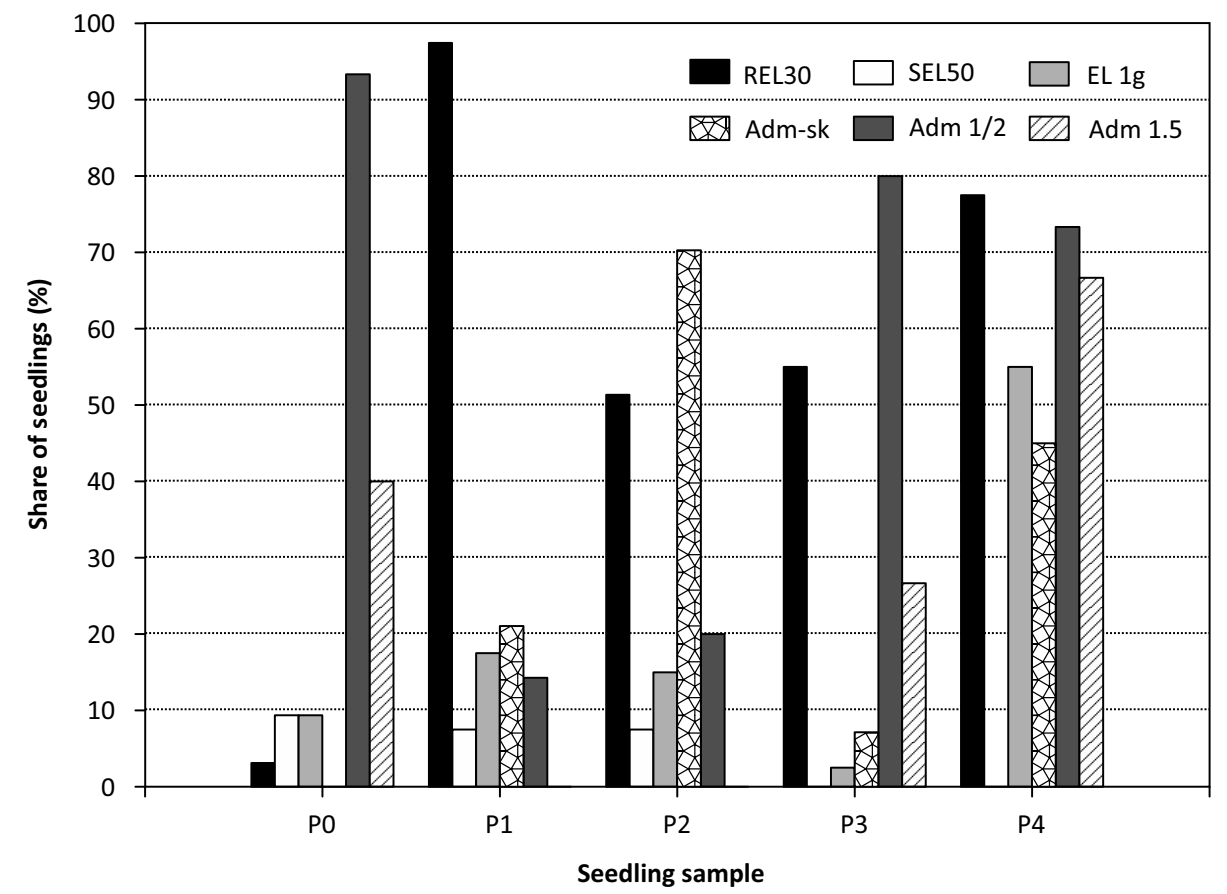

Fig. 1. Share of the seedlings possibly damaged or non-viable, assessed based on the relative electrolyte leakage from the roots (REL30), maximum electrolyte leakage from $1 \mathrm{~g}$ of fresh root mass $\left(E L_{1 g}\right)$, relative electrolyte leakage from the shoot (SEL50) and admittance measured at root collar $\left(A d m_{s k}\right)$ as well as seedlings showing high degree of spring awakening at mid-length of the shoot $\left(A d m_{1 / 2}\right)$ and $1.5 \mathrm{~cm}$ below the top of the shoot $\left(A d m_{1.5}\right)$

Assessment of seedling viability based on the amount of electrolyte leakage from 1 $\mathrm{g}$ of fresh root mass $\left(E L_{1 g}\right)$ did not show a high level of damage to the root system in seedlings in samples P1, P2 and P3, while in sample P4 it determined the share of nonviable seedlings at 55\% (Fig. 1).

The regression relationship between the growth parameters of seedlings and the values of relative electrolyte leakage from roots $(R E L)$ and shoots $(S E L)$ proved to be significant only in the case of REL. Along with the increase in height and slenderness ratio of seedlings, an increased electrolyte leakage from fine roots can be expected, which is a sign of damage and reduction of seedling viability. In both cases, this correlation was well described by the exponential equation, with $R^{2}$ coefficients above 0.32 . However, no such correlation was observed for root collar thickness (Fig. 2). 

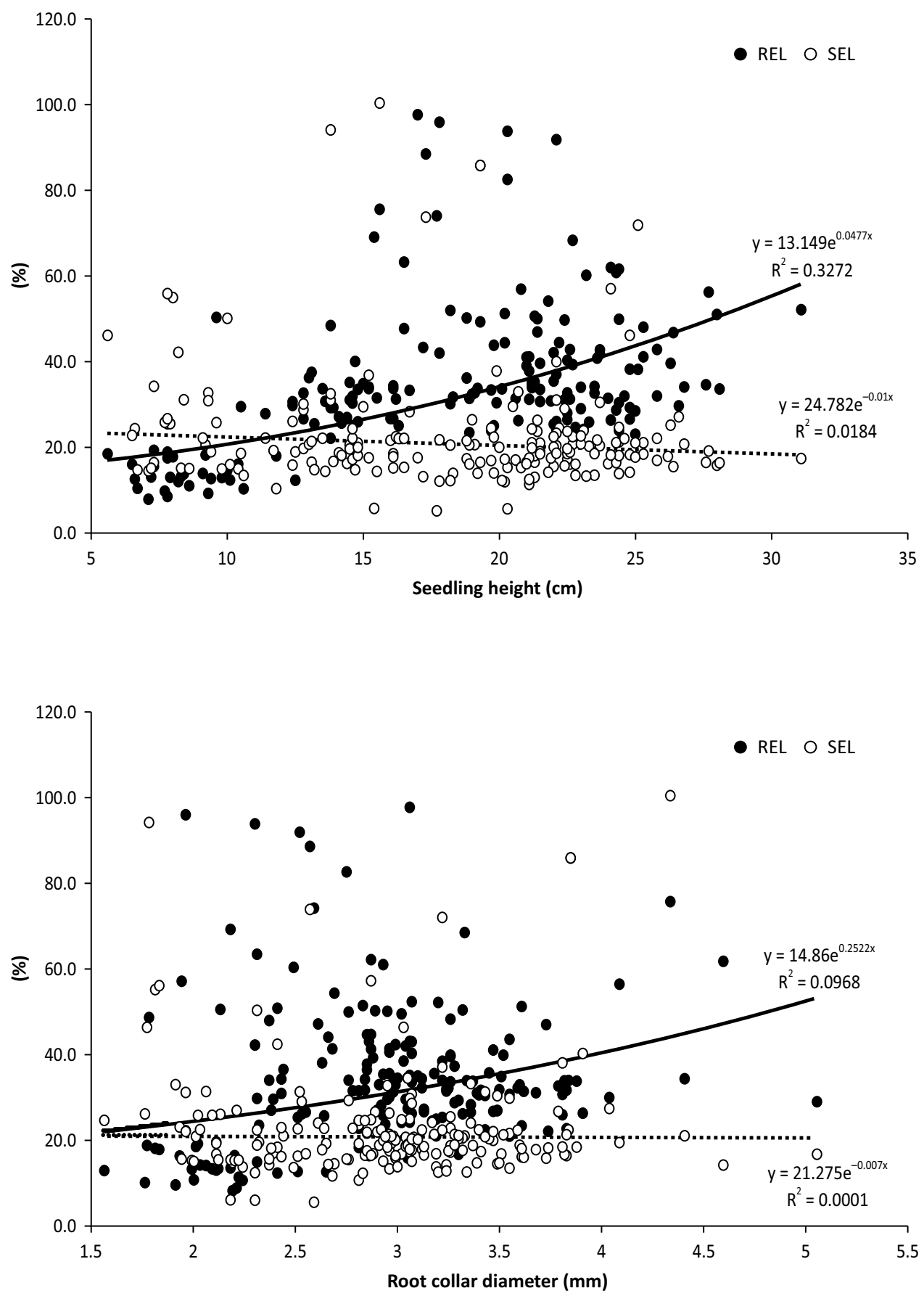

Fig. 2. Regression relationship between growth parameters of seedlings and the value of relative electrolyte leakage [\%] from the roots (REL) and the shoot (SEL) 


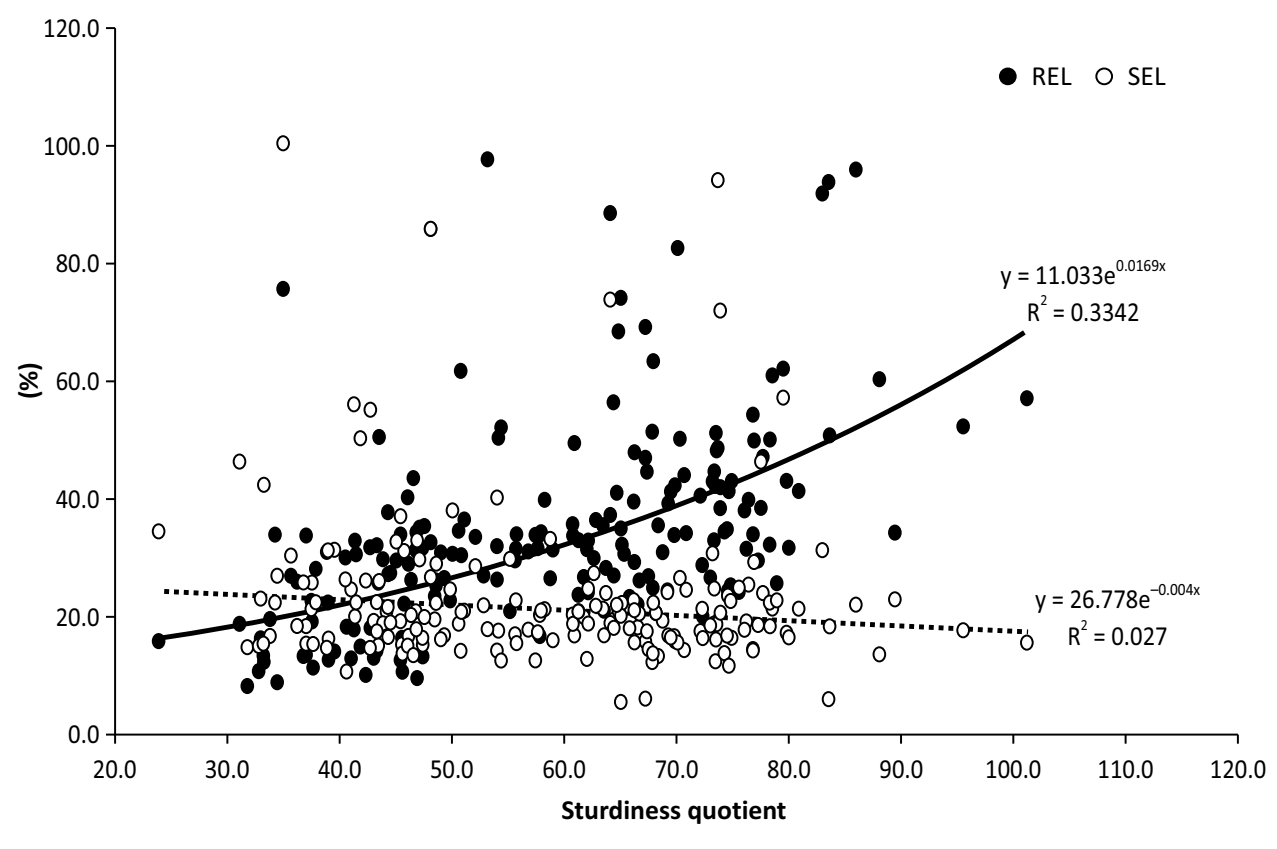

Fig. 2. cont.

\section{Discussion}

Most plant life support processes are temperature dependent. This is associated with the thermal adaptation of enzymatic proteins, the stage of plant development, and its growing conditions. Thermal stress occurs when the plant is exposed to a temperature that deviates from the optimal (Floryszczak-Wieczorek 2007). After an active period of growth at the beginning of summer, trees begin to prepare for winter long before adverse conditions set in. Meristematic activity of the apical buds ceases in response to the shortening of the length of the day, which concludes in stopping growth and the beginning of the resting phase (Welling and Palva 2006). After the autumn acclimatization period, trees are able to tolerate water crystallization outside the cell, and water loss by the cells during this time. Cell freezing temperature is lowered by increased cytoplasm density and partial water loss. The mechanism of immunity is stimulated by the action of plant hormones, and above all, in the final phase, by abscisic acid. The formation of ice crystals in apoplast is not yet a critical, nor irreversible, situation for the cell. Irreversible damage can be observed when ice crystals form in the symplast, therefore frost resistance is mainly based on the formation of ice outside the cell membrane. One of the most important defense mechanisms is the so-called frost plasmolysis, which involves the penetration of water into the apoplast, and prevents "liquid undercooling" (Kopcewicz et al. 2012). Reactions caused by frost, to a large extent, resemble the conditions corresponding to the water deficit. The consequence 
of this is a change in protein conformation, and abnormal reactions between the cell wall and its membrane. All these processes lead to stopping photosynthesis in the plant (Floryszczak-Wieczorek 2007). The described changes occurring at the cellular level allow the plant to survive the adverse winter period, however, in the early spring higher temperatures may alternate with very low temperatures, which may cause significant tissue damage. This is particularly important in the production of seedlings using the container method, where the seedlings grow in a small volume of the substrate, and in addition, during the winter the containers are placed on the ground. This can promote damage to the shoots and roots, mainly to fine roots ( $<2 \mathrm{~mm}$ thick).

The conducted electrolyte leakage analyses showed that, compared to the production with the bare root system, container seedlings of Scots pine were more damaged, except for P3 seedlings, originating from the Rudy Raciborskie Forest District. Although a relatively high share of seedlings exceeding the REL30 value would suggest significant damage to the root systems, the $E L_{1 g}$ indicator close to zero did not confirm this suggestion. Obtained differences may result from a different tolerance range of seedlings of the given origin to low temperature. Scots pine has a high temperature tolerance. It can grow in the conditions of a long day and a short growing season and in the polar region, where the absolute minimum exceeds $-50^{\circ} \mathrm{C}$. At the same time, it grows far south in the conditions of a short day and warm climate, with a temperature of around $+40^{\circ} \mathrm{C}$ (Jaworski 2011). Individual development phases have their specific ranges of thermal stress tolerance. A good example are pine seeds, which originated in Norway and were able to germinate already at $2-4^{\circ} \mathrm{C}$, but for a very long time. Christersson (1983) stated that during the growing season, pine seedlings originating in Norway are damaged only at a temperature of $-8^{\circ} \mathrm{C}$. In turn, freezing the roots of pine seedlings stored at a constant temperature below $-20^{\circ} \mathrm{C}$ led to no growth occurring in the following growing season. The differences in viability between seedlings with bare and container root system could have been affected by the presence of mycorrhizal fungus Hebeloma crustuliniforme in the latter. However, this is contradicted by the lack of differentiation in frost resistance of mycorrhizal and non-mycorrhizal Scots pine seedlings, demonstrated by Korhonen and others (2019) in laboratory studies.

According to Wesoły and Pukacki (2009), vitality tests in nurseries in which seedlings with container root systems are grown should be performed compulsorily because of the higher risk of frost damage. As for soil nurseries, the decision to perform frost resistance tests must be made in the event of suspected freezing of the root or obvious signs of damage. The research shows that these tests should be conducted even if we do not observe frost damage. Despite the fact that the P0 sample came from traditional production (bare root system), slightly more damage was found in these seedlings compared to the $\mathrm{P} 3$ sample from the container nursery. It is recommended to test seedlings early for viability, even if no changes in appearance have been observed, as they may have already occurred at the cellular and molecular level. According to Wesoły and Pukacki (2009), freezing of roots can affect as many as between $80 \%$ and $100 \%$, and this is one of the most serious problems in growing seedlings by container technology. The obtained results indicate that it would be advisable to always perform

acta silvestria • vol. LVI • 2019 • 7-21 
vitality analyses at the end of the winter period, taking into account the provenance of the tested seedlings.

Frost resistance testing using electrolyte leakage was initially mainly used in crops. Rybka (1992) used the assessment of frost resistance of crop plants using various physiological and biochemical methods, stating that the method of electrolyte leakage can be used for other types of stress factors that cause damage to cell membranes. Matuszak-Slamani and Brzóstowicz (2015) studied the effect of different levels of soil salinity and low temperature on frost resistance of Amilo rye seedlings, while Marosz (2014) analysed the electrolyte leakage of new varieties of ornamental shrubs that were grown in the field. He focused mainly on the differences between forsythia, Weigela, and cinquefoil varieties. The method of assessing the degree of frost resistance by means of electrolyte leakage is also used in model plants, e.g. Arabidopsis thaliana (Kurbidaeva et al. 2014). The research results quoted earlier prove the universality of this method.

\section{Conclusions}

1. It is recommended to test the viability of seedlings at the end of the winter, even if no signs of damage were observed, as they may have occurred at the cellular level.

2. Assessment of the amount of electrolyte leakage from root and shoot cells released as a result of frost damage is a good and quick indicator in the analysis of seedling viability.

3. Pine seedlings from container cultivation, wintering in the external production field, have a higher share of damage caused by low temperature, compared to seedlings with a bare root system, wintering in the nursery substrate.

4. A differentiation was found between the provenances of seedlings in terms of all the analysed indicators of viability, which points to varying degree of resistance of cell membranes to damage caused by low temperature.

5. Classification of seedlings as damaged, based on clear signs of damage, was confirmed in $80 \%$ by a low rating of their viability.

6. With the increase in height and the value of the seedling sturdiness quotient (SQ), the share of seedlings showing damage to the root system increases - as reflected by a higher $R E L$ value.

\section{Acknowledgements}

The authors wish to thank the Rudy Raciborskie Forest District for providing nursery material for the research, and MSc. Katarzyna Skowyra, Eng. for her help in laboratory analyses. 


\section{References}

Brønnum P. 2005. Preplating indicators of survival and growth of desiccated Abies procera bere root planting stock. Scandinavian Journal of Forest Research, 20: 36-46.

Brzóstowicz A., Prokowski Z. 2003. Konduktometryczna metoda oceny mrozoodporności roślin. Acta Agrophysica, 93.

Christersson L. 1983. Frost damage during the growing season. In: Plant production in the north workshop: proceedings, September 4-9, Tromso, Norway: 191-198.

Edwards C. 1998. Testing plant quality. Forestry Commission Information Note, Edinburgh, 11: $1-6$.

Floryszczak-Wieczorek J. 2007. Reakcje roślin na niekorzystne czynniki środowiskowe. W: Fizjologia roślin od teorii do nauk stosowanych. Red. M. Kozłowska. PWRiL, Poznań: 485-493.

Gusta L.V., Wisniewski M., Tanino K.K. (eds.). 2009. Plant Cold Hardiness: From the Laboratory to the Field. Centre for Biosciences and Agriculture International, Oxfordshire, 10.1079/9781845935139.0000

Jaworski A. 2011. Charakterystyka hodowlana drzew i krzewów leśnych. W: Hodowla lasu. T. III. PWRiL, Warszawa.

Kopcewicz J., Szmidt-Jaworska A., Kannenberg K. 2012. Zarys struktury i fizjologii drzew leśnych. Wydawnictwo Naukowe Uniwersytetu Mikołaja Kopernika, Toruń.

Korhonen A., Lehto T., Heinonen J., Repo T. 2019. Whole-plant frost hardiness of mycorrhizal (Hebeloma sp. or Suillus luteus) and non-mycorrhizal Scots pine seedlings. Tree Physiology, 39(4): 526-535. DOI: 10.1093/treephys/tpy105

Kurbidaeva A.S., Novokreshchenova M.G. 2011. Genetic Control of Plant Resistance to Cold. Russian Journal of Genetics, 47(6): 646-661.

Kurbidaeva A., Ezhova T., Novokreshchenova M. 2014. Arabidopsis thaliana ICE2 gene: Phylogeny, structural evolution and functional diversification from ICE1. Plant Science, 229: 10-22.

Marosz A. 2014. Ocena mrozoodporności nowych odmian krzewów ozdobnych uprawianych $w$ warunkach polowych na podstawie wycieku elektrolitów. Zeszyty Naukowe Instytutu Ogrodnictwa, 22: 83-91.

Matuszak-Slamani R., Brzóstowicz A. 2015. Influence of salt stress on growth and frost resistance of three winter cereals. International Agrophysics, 29: 193-200. DOI: 10.1515/intag-2015-0018

McKay H.H. 1992. Electrolyte leakage from fine roots of conifer seedlings: a rapid index of plant vitality following cold storage. Canadian Journal of Forest Research, 22: 1371-1377.

Rakowski K. 2005. Fizjologiczne i molekularne podstawy reakcji drzew na stresy środowiskowe. Część II. Wpływ fluorowodoru i niskich temperatur. Leśne Prace Badawcze, 2: 93-105.

Rybka Z. 1992. Fizjologiczno-biochemiczne kryteria oceny mrozoodporności roślin uprawnych. Biuletyn Instytutu Hodowli i Aklimatyzacji Roślin, 183: 31-35.

Sakai A., Larcher W. 1987. Frost survival of plants responses and adaptation to freezing stress. Springer-Verlag, Berlin, Haidelberg.

StatSoft. Inc. 2017. Statistica (data analysis software system) version 13.1. www. StatSoft.com.

Stattin E., Lindström A. 1999. Influence of soil temperature on root freezing tolerance of Scots pine (Pinus sylvestris L.) seedlings. Plant and Soil, 217: 173-181.

Welling A., Palva A.T. 2006. Molecular control of cold acclimation in trees. Physologia Plantarum, 127: $167-181$.

Wesoły W., Hajdasz M. 2014. Przechowywanie sadzonek sosny zwyczajnej (Pinus sylvestris L.) przez zimę w różnych warunkach. Zarządzanie Ochroną Przyrody w Lasach, 8: 238-245. DOI: $10.5604 / 20811438.1158093$ 
Wesoły W., Pukacki P.M., Naparty E. 1998. Zastosowanie metod biofizycznych do oceny żywotności sadzonek sosny, świerka i modrzewia. Sylwan, 142 (8): 55-64.

Wesoły W., Pukacki P., Hauke M. 2004. Instrukcja oceny zmrożenia korzeni sadzonek w szkótce. Dyrekcja Generalna Lasów Państwowych, Warszawa, 1-7.

Wesoły W., Pukacki P.M. 2009. Testy i metody oceny uszkodzeń mrozowych sadzonek drzew leśnych. W: Szkółkarstwo leśne od A do Z. Red. W. Wesoły, M. Hauke. Centrum Informacyjne Lasów Państwowych, Warszawa, 369-375.

Wilczyński S., Durło G., Feliksik E. 2005. Przymrozki wczesne i późne na Kopciowej [Beskid Sadecki]. Acta Agraria et Silvestria, ser. Silvestris, 43: 65-76.

Wisniewski M., Gusta L.V. 2014. The biology of cold hardiness: Adaptive strategies. Environmental and Experimental Botany, 106: 1-3. DOI: 10.1016/j.envexpbot.2014.03.001

\section{PRZEWODNICTWO ELEKTROLITÓW WEWNĄTRZKOMÓRKOWYCH JAKO SZYBKI WSKAŹNIK ŻYWOTNOŚCI SADZONEK SOSNY ZWYCZAJNEJ PO ZIMOWANIU W WARUNKACH POLOWYCH}

\section{STRESZCZENIE}

Sadzonki hodowane w szkółkach stosujących technologię kontenerową są narażone na termiczny stres środowiskowy, będący efektem niskich temperatur w okresie zimowym w połączeniu z brakiem pokrywy śnieżnej. Najbardziej narażony na uszkodzenia jest system korzeniowy, a najszybciej przemarzają korzenie o średnicy poniżej $2 \mathrm{~mm}$. Sadzonki oceniane wzrokowo mogą nie wykazywać wyraźnych objawów uszkodzenia lub obniżenia żywotności, jednak uszkodzenie może wystąpić na poziomie komórkowym rośliny. Z tego wynika potrzeba oceny żywotności sadzonek i ich kondycji fizjologicznej. Celem pracy była analiza żywotności oraz zróżnicowania stopnia odporności na niską temperaturę jednorocznych sadzonek sosny zwyczajnej (Pinus sylvestris L.), wyhodowanych w kontenerach Hiko V120ss, które zimowały na zewnętrznym polu produkcyjnym w szkółce kontenerowej. Materiał szkółkarski został wyhodowany z nasion zebranych w 4 obiektach nasiennych rosnących w nadleśnictwach: Kędzierzyn (P1), Chrzanów (P2), Rudy Raciborskie (P3) oraz plantacji nasiennej w Nadleśnictwie Miechów (P0). Dodatkowo przeanalizowano również próbkę sadzonek wykazujących objawy uszkodzenia (P4) (tab. 1). Zmierzono przewodnictwo elektryczne elektrolitów uwolnionych z pędów (SEL - Shoot Electrolyte Leakage) oraz korzeni (REL - Root Electrolyte Leakage) sadzonek sosny. Otrzymane wyniki porównano z oceną przewodnictwa elektrycznego $(E C)$ pędu i korzenia (tzw. admitancji) tych samych sadzonek. Przy użyciu równań regresyjnych oceniono zależność między parametrami wzrostowymi sadzonki a wartością SEL i REL. Sadzonki sosny z hodowli kontenerowej, zimujące na zewnętrznych polach hodowlanych, wykazały większy udział uszkodzeń spowodowanych niską temperaturą $\mathrm{w}$ porównaniu z sadzonkami z nagim systemem korzeniowym, zimującymi w sztucznym podłożu po hodowli w namiocie foliowym. Wykazano zróżnicowanie między po- 
szczególnymi proweniencjami pod względem wszystkich analizowanych wskaźników żywotności, co wskazuje na różny stopień odporności błon komórkowych na uszkodzenia spowodowane niską temperaturą (tab. 2). Zaklasyfikowanie sadzonek do grupy uszkodzonych na podstawie wizualnej oceny występowania objawów uszkodzeń zostało potwierdzone w $80 \%$ pomiarem ich żywotności (ryc. 1). Wraz ze wzrostem wysokości oraz wielkości współczynnika wytrzymałości sadzonek (SQ) zwiększał się udział sadzonek wykazujących uszkodzenia systemu korzeniowego - wyższa wartość REL (ryc. 2). Na podstawie przeprowadzonych badań zaleca się badanie żywotności sadzonek pod koniec okresu zimowego, nawet jeśli nie zaobserwowano objawów uszkodzeń, ponieważ mogły one wystąpić na poziomie komórkowym. Ocena poziomu wycieku elektrolitu z komórek korzeni i pędu uwolnionych na skutek uszkodzeń mrozowych jest dobrym i szybkim wskaźnikiem żywotności sadzonek.

\section{SŁOWA KLUCZOWE}

uszkodzenia mrozowe • żywotność • admitancja • REL • SEL 